\title{
Assessment of Lead and Zinc Profile from Vehicle Emission in Roadside Fodder Plants
}

\author{
KAFEEL AHMAD ${ }^{1}$, NAILA SANA ${ }^{1}$, SONAINA NAZAR ${ }^{1}$, ZAFAR IQBAL KHAN ${ }^{1 *}$, \\ HUMAYUN BASHIR ${ }^{1,2}$, MUHAMMAD NADEEM ${ }^{3}$, PERVAIZ AKHTER ${ }^{1}$, \\ MUDASRA MUNIR ${ }^{1}$, AHMED HOSSAM MAHMOUD ${ }^{4}$, OSAMA B MOHAMMED ${ }^{4}$, \\ ASMA ASHFAQ ${ }^{1}$, IFRA SALEEM MALIK ${ }^{1}$ \\ ${ }^{1}$ Department of Botany, University of Sargodha, University Road, 40100, Sargodha, Pakistan \\ ${ }^{2}$ Institute of Molecular Biology and Biotechnology, The University of Lahore, Defense Road, 54792, Lahore, Pakistan \\ ${ }^{3}$ Institute of Food Science and Nutrition, University of Sargodha, University Road, 40100, Sargodha, Pakistan \\ ${ }^{4}$ Zoology Department, College of Science, King Saud University, Riyadh 11451, Saudi Arabia
}

\begin{abstract}
Due to increasing population and increasing number of automobiles the fodder samples were collected from Khushab District along the roadside to examine the heavy metal contamination. It was a serious issue because animals consume these contaminated fodders and then they enters the food chain where they cause toxicity. Five fodder plants Pennisetum glaucum, Trifolium alexandrinum, Saccharum officinarum, Zea mays and Brassica compestris were selected for sampling. The sampling of selected fodder plants and their soil was done during November which was the driest season of Khushab city and the dust and smoke was present on the fodder plants. The samples were air and oven dried. Then subjected to digestion. Acid digestion was done with Nitric acid $\left(\mathrm{HNO}_{3}\right), \mathrm{Hydrogen} \mathrm{peroxide}\left(\mathrm{H}_{2} \mathrm{O}_{2}\right)$ and Hydrogen chloride (HCL). The samples become transparent and the heavy metal analysis of both soil and fodder samples was done through Atomic absorption spectrophotometer (AASP). Lead and zinc heavy metals were analyzed. The pollution load index was lower than 1 which indicates that there was low concentration of metal in soil of the collected samples of the current study. It was obtained that the soil was less polluted. The daily intake of metals was lower than 1 that concluded that they were at safe limit during consumption. The present study showed the enrichment concentration of metals greater than 1 it means these metals were present in both soil and fodder samples growing near roadside.
\end{abstract}

Keywords: Heavy metals, Roadside, Fodder Plants, Daily intake

\section{Introduction}

The word pollution is derived from Latin word "Pollutioneum" meaning to make dirty. Atmospheric pollution can be defines as change in the air constituent due to human activity [1]. According to National Environmental Research Council, pollution can be defined as, release of wasteful substances and energy through human activities that cause harmful changes in the natural environment. Health Effects Institute reported that $95 \%$ of world's population breathe dangerous and polluted air. The presence of one or more contaminants such as dust, smoke, smog that cause injurious effects on human health, plants and animal life, or which interferes with enjoyment of life and property is called Air pollution. The atmospheric pollution is the serious problem of today. It is the more severe type of pollution, it causes declines in environmental conditions. According to this report Pakistan, Bangladesh, India have contributing steepest in increasing air pollution level since 2010. In Pakistan tremendous increase in motor vehicles is $37 \%$ per year. Vehicles emit $20-90 \%$ of cadmium that have negative impacts on green pigment in plants [2].

Plants are very important to enhance the air quality by absorbing gases and particles from the air especially in urban areas [3]. The effective indicator of overall air pollution are plants. Plants are mostly used for the determination of air pollutants in a very short time. So that, the trees and Shrubs are used as dust filters to determine the increasing heavy metal and dust pollution level of atmosphere [4].

*email: zafar.khan@uos.edu.pk 
Increased road transportation and industrialization cause the release of high concentration of heavy metals and harmful gases [5]. Air pollution have negative effects on environment and living organisms worldwide. Heavy traffic cause harmful effects on fodder crops near roadside area [6]. Air pollutants enter in to the plants through leaves and soil. Due to exposure to the air, harmful particles present in the air, when enters to these leaves cause changes to their physiology [7]. Industries and vehicles are accountable for emissions of air particles and harmful gases and particles are pointers of air pollution and fodder plants are very delicate to them [5].

Air pollutants when emitted cause deleterious effects on human, plants and also on environment [89]. Roadside plants are major victims of these air pollutants and thus have negative effects like they stop growth, damaging of leaves veins, maturity level becomes delayed, premature leave aging, early abortion of flower, and also effect quality and yield of plant [10-11].

In humans, increased level of these air pollutants cause severe and long lasting effects e.g. Respiration diseases early maturity, tumor of lungs, long lasting lung and heart diseases in humans. Many investigators study about the response of plants to these pollutants and also their effects on their structure, function and biochemistry. In the environment all plant species have a various impacts on different pollution type depending upon the ecological conditions. It is assumed that automobile pollution is more dangerous than any other type of pollution because humans mostly stay near automotive exhaust. Thus, through respiration these particles are inhaled directly [12-16].

In delicate class of plant species the automobile emissions cause damage to the leaf, stomata that leads to the early aging and reduce photosynthesis [17]. When the leaf damaged by air pollutants leaf size and number decreases and hence the radiations cannot enter into the leaves so the photosynthesis reduced or stops. When plants faced the polluted environment leaf surface area and petiole length reduced [17-18]. Many previous research workers also put forward the comparison of effect of polluted and non-polluted environment [19]. This study is planned to assess the heavy metal profile in soil and fodder plants contaminated with vehicular exhaust near roadside area.

\section{Materials and methods}

\subsection{Study area}

Khushab District

Khushab city is found in Punjab Pakistan. It is located at 32.30 latitude and 72.35 longitude. Its situation is 186 meters above the sea level. It is $38^{\text {th }}$ biggest city in Punjab province. In Punjab province it is located between cities of Sargodha and Mianwali. The word Khushab means sweet water. It consists of agricultural lowlands, hills and lakes. The district has four Tehsils, Khushab, Noor PurThal, Qaidabad and Naushera. Its population was 110,868 at the time of 2009. The area code of Khushab is 0454 . The increase in population occurs day by day so, the traffic density also become increased to large extent on the roads. The current study based on the heavy metal analysis coming from the vehicular exhaust along roadside fodder plants. Livestock farmers are mainly dependent on the green fodders grown in this area.

\subsection{Collection of samples Forage samples}

Total 120 samples of five fodders Pennisetumgluacum, Zea mays, Brassica compestris, Trifoliumalexanderium, Saccharumofficinarum (Bajra, Makai, Sarson, Barseem and Gunna) respectively were collected from four sites of Sargodha to Khushab road (Table 1). Two samples of each fodder plant were collected, one from the edge of the road and one away from the road. Two replicates of each of above two samples were collected. Fodder samples were collected in polythene bags.

\section{Soil Samples}

The samples of soil were collected from the four sites of sampling near road from Sargodha to Khushab. 120 replicates of soil of each plant were collected. Each of these (1kg sample of soil) were 
collected in polythene bags by digging soil about $15-30 \mathrm{~cm}$ deep with the help of shovel. The 0-25 $\mathrm{cm}$ depth was considered to represent the plough layer and average root zone for nutrients uptake and heavy metals burden by plants.

Table 1. List of Fodders

\begin{tabular}{|c|c|c|c|}
\hline Sr. No & Common Name & Scientific name & Family \\
& & & \\
\hline 1 & Barseem & Trifolium alexanderium & Fabaceae \\
\hline 2 & Corn & Zea mays & Poaceae \\
\hline 3 & Sarson & Brassica compestris & Brassicacea \\
\hline 4 & Pearl millet & Pennisetum gluacum & Poaceae \\
\hline 5 & Sugarcane & Saccharum officinarum & Poaceae \\
\hline
\end{tabular}

\subsection{Sample Preparation}

\section{Preparation of Fodder samples}

Plants were first placed in open air and then transferred to oven at $72^{\circ} \mathrm{C}$ till all the moisture contents are removed. Then these dried samples were converted into powder form and stored in plastic bags until used for digestion. Wet digestion method was used for the digestion of fodder samples. Samples were digested in $5 \mathrm{~mL}$ of $68 \% \mathrm{HNO}_{3}$ for $24 \mathrm{~h}$. Then put into digestion chamber and heat it and removed until when the evaporation of fumes stops. Then $5 \mathrm{~mL}$ of $30 \% \mathrm{H}_{2} \mathrm{O}_{2}$ were added and again heated until it becomes colorless. By adding the filtered distilled water the digested samples were made up to $50 \mathrm{~mL}$ and kept in labeled plastic bottles [20]. The solution was then taken toatomic absorption Spectrophotometer for heavy metal analysis. The sample preparation procedure was performed according to [20].

\section{Preparation of Soil samples}

Soil samples was air dried at room temperature and then oven dried at $70^{\circ} \mathrm{C} .0 .5 \mathrm{~g}$ of soil samples were subjected to digestion chamber. $0.5 \mathrm{~g}$ of sample and $20 \mathrm{~mL}$ of $\mathrm{HNO}_{3}$ was added in digestion tubes. Heat the tubes in digestion chamber. Add $5 \mathrm{~mL}$ of $\mathrm{H}_{2} \mathrm{O}_{2}$ was added and then heated again until it becomes colorless [20]. By adding distilled water the samples were made up to $50 \mathrm{~mL}$. Then the samples were stored in plastic bottles. These solutions were then subjected to Atomic absorption spectrophotometer for analysis of heavy metals.

\subsection{Standard Preparation:}

The standards were prepared by using following methods

$>$ To make the standard solution glass were used and it must be clean. $100 \mathrm{~mL}$ volumetric flask and funnel were washed with de-ionized water.

$>$ Analytic balance was used to weight the sample in a beaker.

$>$ Small volume of sample or another solvent can be used to dissolve the sample

$>$ The sample was completely dissolved in solution. To speed the process of dissolution hot plate was used.

$>$ Volumetric flask was used to pour the sample quantitatively. Beaker, funnel and stirring rod was washed completely with de-ionized water. Sample was transferred to the flask.

$>$ The beaker was washed with de-ionized water for few minutes

$>$ Made a mark below $100 \mathrm{~mL}$ on volumetric flask and then filled it with few $\mathrm{mL}$.

$>$ By using dropper add few drops of de-ionized water so that meniscus touched the mark that was placed on the flask.

$>$ Shake the flask for few minutes to mix it thoroughly

$>$ Make sure that solution becomes homogeneous

$>$ At the end again checked that meniscus touch the mark of $100 \mathrm{~mL}$ at volumetric flask 


\subsection{Instrumentation}

Table 2. Parameters of Instrument used for detection of heavy metals

\begin{tabular}{|c|c|c|c|c|}
\hline Element & $\begin{array}{c}\text { Lamp current } \\
(\mathrm{mA})\end{array}$ & $\begin{array}{c}\text { Wavelength } \\
(\mathrm{nm})\end{array}$ & Slit Width(nm) & $\begin{array}{c}\text { Instrument } \\
\text { detection(mg/l) }\end{array}$ \\
\hline $\mathrm{Cd}$ & 4 & 228.8 & 0.5 & 0.0020 \\
\hline $\mathrm{Fe}$ & 5 & 248.3 & 0.2 & 0.0060 \\
\hline $\mathrm{Mn}$ & 5 & 279.5 & 0.2 & 0.0020 \\
\hline $\mathrm{Zn}$ & 5 & 213.9 & 1.0 & 0.0010 \\
\hline $\mathrm{Pb}$ & 5 & 217.0 & 1.0 & 0.0010 \\
\hline $\mathrm{Ni}$ & 4 & 232.0 & 0.2 & 0.0010 \\
\hline $\mathrm{Cr}$ & 7 & 357.9 & 0.2 & 0.0010 \\
\hline $\mathrm{As}$ & 10 & 193.7 & 0.5 & \\
\hline
\end{tabular}

\section{Mineral analysis:}

Plants and soil samples were directed towards the Atomic Absorption spectrophotometer for heavy metal analysis. The Atomic absorption spectrophotometer Perkin-Elmer AAS-5000 (Perkin-Elmer Corp, 1980), was used after acid digestion (Table 2). It was used to analyze the heavy metals lead (Pb) and Zinc $(\mathrm{Zn})$ in the present study. As was analyzed through using graphite furnace.

\subsection{Statistical analysis}

SPSS (Special Programme for social sciences) was used for the analysis of variance and correlations. Variance analysis of heavy metals in soil and fodder plants was determined by two way ANOVA. The soil to fodder correlation was determined. Significance of mean values was at $0.05,0.001$, 0.01 probability levels reported by [21].

\subsection{Bio-Concentration Factor (BCF)}

The concentration of heavy metal in fodder sample from soil to fodder is called as bio concentration factor (on the basis ofdry weight).

\section{Bio-concentration factor $=\mathbf{C}_{\text {fodder }} / \mathbf{C}_{\text {soil }}$}

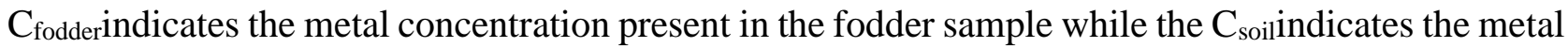
concentration present in the soil, $\mathrm{mg} / \mathrm{kg}$ dry weight [22].

\subsection{Daily Intake of Metals (DIM)}

The formula to determine the daily intake of metal was given by [23].

\section{$\mathrm{DIM}=\mathbf{C}_{\text {metal }} \times \mathbf{C}_{\text {daily food intake }} \times$ Conversion factor $/ \mathbf{B}_{\text {average weight }}$}

$\mathrm{C}_{\text {metal }}$ indicates the concentration of metals, $\mathrm{C}_{\text {daily food intake }}$ indicates the consumption of fodder by cattle per day in $\mathrm{Kg}$, the value of Conversion factor was 0.085 , the $\mathrm{B}_{\text {average weight }}$ represents the average body weight of buffalo of the selected sampling site. The average consumption of fodder by animal was $12.5 \mathrm{Kg}$ and average body weight was $550 \mathrm{Kg}$ per cattle [24].

\subsection{Health Risk Index (HRI)}

To determine the health risk of heavy metals through ingestion of contaminated fodders health risk index was calculated. This can be calculated by dividing the daily intake of metal to oral reference dose [25].

\section{HRI $=D I M / R_{f} D$}

DIM indicates the daily intake of metal while $\mathrm{R}_{\mathrm{f}} \mathrm{D}$ indicates the oral reference dose of animal.

The oral reference dose of metals was 


\subsection{Enrichment Factor: (EF)}

It can be defined as the withholding of metal in soil and it depends upon the availability of metal in soil. It was used to find the concentration of metal present in the soil.

\section{$\mathbf{E F}=$ concentration of metals in the amended soil/concentration of metals in the controlled soil [26]}

\section{Pollution Load Index}

The pollution load index helps us to determine the concentration of heavy metal in the soil.

\section{$\mathbf{P L I}=\mathbf{C}_{\text {soil }} / \mathbf{C}$ reference value}

$\mathrm{C}_{\text {soil }}$ denotes investigated concentration of metal in the soil and $\mathrm{C}_{\text {reference value indicates the reference }}$ value of soil for each metal [27].

\subsection{Correlation}

The correlation coefficient of metal concentration in soil and fodder samples were determined by using (SPSS) abbreviated as Statistical program for social sciences. To determine the correlation of metal from soil to fodder one way ANOVA was used in the current study.

\section{Results and discussions}

\subsection{Soil}

The analysis of variance of $\mathrm{Pb}$ in soil showed significant effect on Sites, Treatment, Fodders, Sites * Treatment, Sites * Fodders, Treatment * Fodders, Sites * Treatment * Fodders (Table 3). The significant effect was showed in analysis of variance of data for $\mathrm{Zn}$ Sites, Treatment, Fodders, Sites * Treatment, Sites $*$ Fodders, Treatment $*$ Fodders, Sites * Treatment $*$ Fodders (Table 4).

Table 3. Analysis of variance of data for $\mathrm{Pb}$ in soil from four road sites

\begin{tabular}{|c|c|c|}
\hline SOV & Degree of freedom & Mean square \\
\hline Sites & 3 & $129.957^{* * *}$ \\
\hline Treatment & 1 & $47.066^{* * *}$ \\
\hline Fodders & 4 & $21.155^{* * *}$ \\
\hline Sites* Treatment & 3 & $19.363^{* * *}$ \\
\hline Sites * Fodders & 12 & $24.215^{* * *}$ \\
\hline Treatment * Fodders & 4 & $28.019^{* * *}$ \\
\hline Sites * Treatment * Fodders & 12 & $47.259^{* * *}$ \\
\hline Error & 80 & 0.217 \\
\hline
\end{tabular}

Table 2. Analysis of variance of data for $\mathrm{Zn}$ in soil from four road sites

\begin{tabular}{|c|c|c|}
\hline SOV & Degree of freedom & Mean square \\
\hline Sites & 3 & $277.733^{* * *}$ \\
\hline Treatment & 1 & $570.946^{* * *}$ \\
\hline Fodders & 4 & $71.483^{* * *}$ \\
\hline Sites* Treatment & 3 & $65.981^{* * *}$ \\
\hline Sites * Fodders & 12 & $84.486^{* * *}$ \\
\hline Treatment * Fodders & 4 & $96.247^{* * *}$ \\
\hline Sites * Treatment Fodders & 12 & $78.061^{* * *}$ \\
\hline Error & 80 & 76.915 \\
\hline
\end{tabular}

\subsection{Fodder}

The analysis of variance of data for $\mathrm{Pb}$ showed significant effect on Sites, Sites* Treatment, and significant effect on Treatment, Sites* Fodders and non-significant effect on Fodders, Treatment * Fodders, Treatment* Fodders and Sites * Treatment * Fodders. The analysis of variance for Zn showed significant effect on Sites, Fodders, Sites * Treatment, Sites * Fodders, Treatment * Fodders, Sites * Treatment $*$ Fodders while non-significant effect on Treatment (Table 6). 
Table 3. Analysis of variance of data for $\mathrm{Pb}$ in fodder plants from four road sites

\begin{tabular}{|c|c|c|}
\hline SOV & Degree of freedom & Mean square \\
\hline Sites & 3 & $288.280^{* * *}$ \\
\hline Treatment & 1 & $24.377^{*}$ \\
\hline Fodders & 4 & $2.820^{\text {ns }}$ \\
\hline Sites * Treatment & 3 & $116.857^{* * *}$ \\
\hline Sites $*$ Fodders & 12 & $8.785^{*}$ \\
\hline Treatment * Fodders & 4 & $4.141^{\text {ns }}$ \\
\hline Sites * Treatment * Fodders & 12 & $3.659^{\text {ns }}$ \\
\hline Error & 80 & 4.025 \\
\hline
\end{tabular}

Table 4. Analysis of variance of data for $\mathrm{Zn}$ in fodders from four sites having high vehicular exhaust

\begin{tabular}{|c|c|c|}
\hline SOV & Degree of freedom & Mean square \\
\hline Sites & 3 & $233.774^{* * *}$ \\
\hline Treatment & 1 & $1.253^{\text {ns }}$ \\
\hline Fodders & 4 & $2.358^{* * *}$ \\
\hline Sites * Treatment & 3 & $66.136^{* * *}$ \\
\hline Sites * Fodders & 12 & $7.983^{* * *}$ \\
\hline Treatment * Fodders & 4 & $16.118^{* * *}$ \\
\hline Sites * Treatment * Fodders & 12 & $5.261^{* * *}$ \\
\hline Error & 80 & .387 \\
\hline
\end{tabular}

\subsection{Mean concentration of heavy metals in fodder Plants}

The highest and lowest mean concentration of $\mathrm{Pb}$ showed that the B.compestris was facing highest contamination of $\mathrm{Pb}$ through vehicles near and even at a distance from the road (Table 7). The highest concentration of $\mathrm{Zn}$ was present in B.compestris of site 1 and lowest (Figure 1) value was present in S.officinarum of site 2 present at some distance from the road (Table 8, Figure 2). The present study showed that the mean concentration $\mathrm{Pb}, \mathrm{Zn}$ of fodder samples collected from roadside were higher as compared to the mean concentration given by [28]. The work done by [28]. The lead concentration was $0.0520 \mathrm{mg} / \mathrm{kg}$ which was lower than the present study. Their work was done along major roads and control sites of Dibete Area. He also analyzed the heavy metal concentration along roadside forage samples. In Nigeria the same work was done by Ogandele, he collected forage sample along major roadsides. The samples were acid digested and analysis of metals were done by Atomic Absorption Spectrophotometer. According to present study range of $\mathrm{Pb}$ was $13.0352 \mathrm{mg} / \mathrm{kg}$ to $2.2152 \mathrm{mg} / \mathrm{kg}$, which was within the range ( 24 to $397 \mathrm{mg} / \mathrm{kg}$ ) as proposed by [29]. The mean concentration of Ni and $\mathrm{Zn}$ were higher as compared to present study while the concentration of $\mathrm{Cd}$ and $\mathrm{Pb}$ was lower [30]. According to Ahmad [31], the levels of heavy metals concentration for $\mathrm{Pb}$ was lower in their forage samples as compared to the current study.

Table 5. Mean concentration of $\mathrm{Pb}$ in fodders from four sites contaminated with vehicular exhaust

\begin{tabular}{|c|c|c|c|c|c|c|}
\hline Sites & Treatments & P.glaucum & T.alexandrinum & S.officinarum & Z.mays & B.compestris \\
& & & & & & \\
\hline \multirow{2}{*}{ Site 1 } & AR & 7.0562 & 7.5520 & 6.8850 & 4.3330 & 6.8410 \\
\cline { 2 - 7 } & NR & 6.2162 & 6.4787 & 7.5845 & 7.4205 & 5.1725 \\
\hline \multirow{2}{*}{ Site 2 } & AR & 4.4382 & 5.2496 & 3.6305 & 3.3047 & 4.7744 \\
\cline { 2 - 7 } & NR & 4.9105 & 2.2265 & 4.6580 & 4.9053 & 2.2152 \\
\hline \multirow{2}{*}{ Site 3 } & AR & 2.2907 & 3.0527 & 3.0847 & 11.8012 & 8.8365 \\
\cline { 2 - 7 } & NR & 9.5643 & 9.7587 & 9.5032 & 2.4895 & 13.0325 \\
\hline \multirow{2}{*}{ Site 4 } & AR & 11.7597 & 13.0973 & 11.5423 & 10.6847 & 10.8030 \\
\cline { 2 - 7 } & NR & 11.9575 & 10.1842 & 10.7693 & 12.1300 & 12.0213 \\
\hline
\end{tabular}


Table 6. Mean concentration of $\mathrm{Zn}$ in fodders from five sites contaminated with vehicular exhaust

\begin{tabular}{|c|c|c|c|c|c|c|}
\hline Sites & Treatments & P.glaucum & T.alexandrinum & S.officinarum & Z.mays & B.compestris \\
& & & & & & \\
\hline \multirow{2}{*}{ Site 1 } & AR & 10.5592 & 10.7720 & 10.6618 & 4.2010 & 11.0570 \\
\cline { 2 - 7 } & NR & 10.6642 & 10.2452 & 10.7960 & 10.2763 & 4.6690 \\
\hline \multirow{2}{*}{ Site 2 } & AR & 4.2017 & 4.7192 & 1.5527 & 2.1125 & 3.6005 \\
\cline { 2 - 7 } & NR & 5.0686 & 2.2995 & 3.8772 & 4.5483 & 1.8845 \\
\hline \multirow{2}{*}{ Site 3 } & AR & 2.0128 & 1.7133 & 1.9630 & 8.1217 & 6.2375 \\
\cline { 2 - 7 } & NR & 7.3767 & 6.5393 & 6.6267 & 2.3454 & 6.0813 \\
\hline \multirow{2}{*}{ Site 4 } & AR & 6.7621 & 6.2918 & 8.7850 & 7.8785 & 8.5588 \\
\cline { 2 - 7 } & NR & 8.5633 & 9.0408 & 8.2085 & 8.8212 & 8.7685 \\
\hline
\end{tabular}

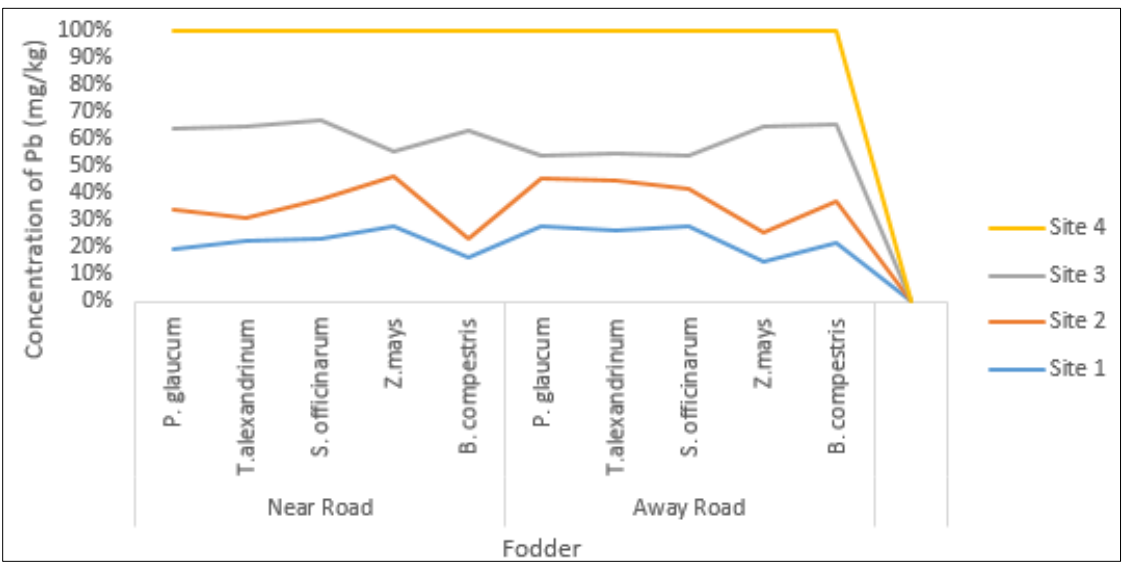

Figure 1. Pb fluctuations in fodders from four road sites of sampling

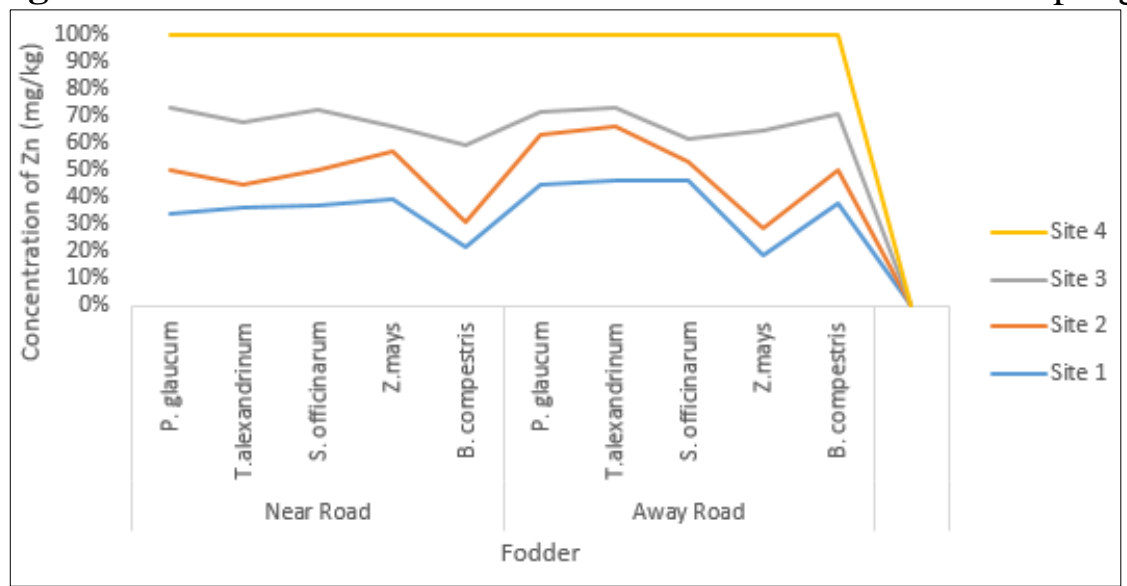

Figure 2. $\mathrm{Zn}$ fluctuations in fodders from four road sites of sampling

\subsection{Mean concentration of heavy metals in soil}

The soil of P.glaucum had highest concentration of $\mathrm{Pb}$ while the Z.mays showed the lowest concentration facing high traffic density (Table 9, Figure 3). The Zn showed highest and lowest concentration in the samples B.compestris and Z. mays fodder samples facing highly traffic pollutants (Table 10, Figure 4). The mean concentration of the zinc is lower as compared to present study [30]. The trend of heavy metal concentration of soil taken roadsides was given as $\mathrm{Fe}>\mathrm{Zn}>\mathrm{Mn}>\mathrm{Pb}>\mathrm{Cd}[32]$. The concentration of metals were lower as compared to the present study. The higher $\mathrm{Zn}$ and Cd level along roadside soil samples were due to high traffic density and lubricating oils which contains $\mathrm{Zn}$ in the form of $\mathrm{Zn}$ dithiophosphates [33]. Opaluwa [34] reported the mean concentration of $\mathrm{Fe}, \mathrm{As}, \mathrm{Pb}, \mathrm{Zn}$, Ni was lower as compared to current study. Mmolawa [35] worked on soil samples along major roadsides of Botswana. He selected soil samples from five sites and analyzed the heavy metals in them. 
The mean concentration given by Mmolawa showed lower values of $\mathrm{Fe}, \mathrm{Mn}, \mathrm{Ni}$, and $\mathrm{Zn}$ as compared to the current study.

Table 7. Mean Concentration of $\mathrm{Pb}$ in Soil at various distances along the road

\begin{tabular}{|c|c|c|c|c|c|c|}
\hline Sites & Treatments & P.glaucum & T.alexandrinum & S.officinarum & Z.mays & B.compestris \\
& & & & & & \\
\hline \multirow{2}{*}{ Site 1 } & AR & 6.2360 & 7.3517 & 6.5338 & 6.6487 & 7.4677 \\
\cline { 2 - 7 } & NR & 8.1152 & 6.2293 & 5.8748 & 7.2912 & 4.0228 \\
\hline \multirow{2}{*}{ Site 2 } & AR & 4.1487 & 5.6590 & 4.2318 & 4.4065 & 5.7683 \\
\cline { 2 - 7 } & NR & 4.8030 & 9.8523 & 8.4347 & 8.1777 & 8.0042 \\
\hline \multirow{2}{*}{ Site 3 } & AR & 8.4307 & 10.1848 & 10.3493 & 8.5850 & 10.0333 \\
\cline { 2 - 7 } & NR & 13.2235 & 10.4850 & 11.5438 & 11.6182 & 11.2957 \\
\hline \multirow{2}{*}{ Site 4 } & AR & 11.0618 & 11.9107 & 2.0442 & 2.0055 & 3.5673 \\
\cline { 2 - 7 } & NR & 3.7783 & 2.0832 & 3.5795 & 3.5450 & 19.7183 \\
\hline
\end{tabular}

Table 8. Mean Concentration of $\mathrm{Zn}$ in Soil along the road from four sampling sites

\begin{tabular}{|c|c|c|c|c|c|c|}
\hline Sites & Treatments & P.glaucum & T.alexandrinum & S.officinarum & Z.mays & B.compestris \\
& & & & & & \\
\hline \multirow{2}{*}{ Site 1 } & AR & 10.0003 & 9.8918 & 10.1072 & 11.5793 & 11.4250 \\
\cline { 2 - 7 } & NR & 11.2262 & 11.6983 & 3.9968 & 11.4345 & 40.8750 \\
\hline \multirow{2}{*}{ Site 2 } & AR & 3.3360 & 3.7797 & 3.5550 & 4.3617 & 4.0118 \\
\cline { 2 - 7 } & NR & 4.6643 & 7.1578 & 6.6658 & 7.2000 & 5.7330 \\
\hline \multirow{2}{*}{ Site 3 } & AR & 6.1152 & 6.8988 & 8.5543 & 7.0552 & 7.0058 \\
\cline { 2 - 7 } & NR & 8.9343 & 7.6922 & 8.9680 & 8.5663 & 7.9033 \\
\hline \multirow{2}{*}{ Site 4 } & AR & 8.7508 & 8.0092 & 1.9237 & 2.2705 & 2.1903 \\
\cline { 2 - 7 } & NR & 1.9030 & 1.8818 & 1.7315 & 1.7170 & 1.7448 \\
\hline
\end{tabular}

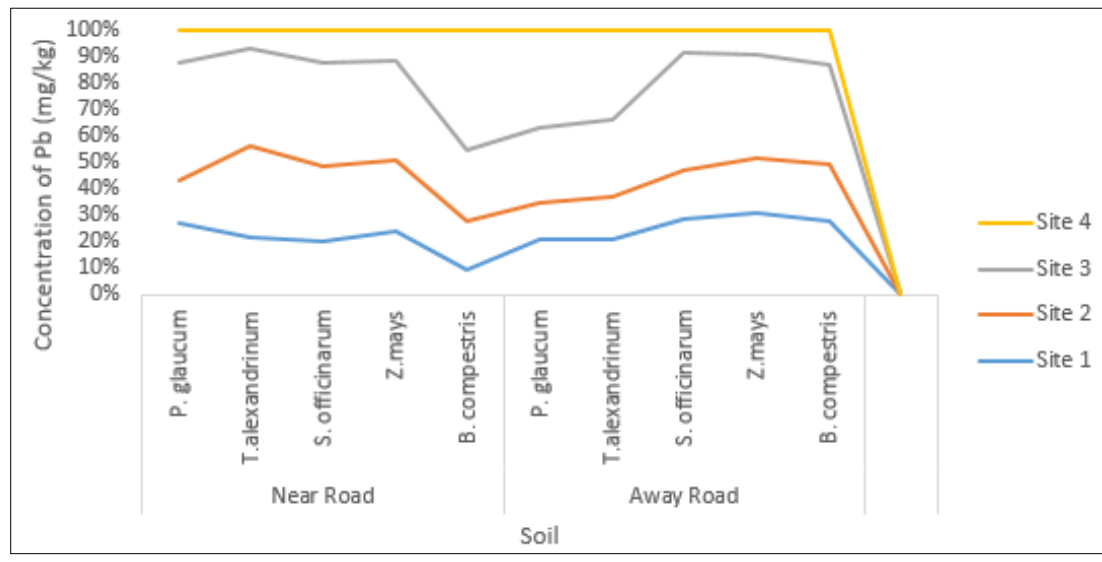

Figure 3. Pb fluctuations in Soil from four road sites of sampling

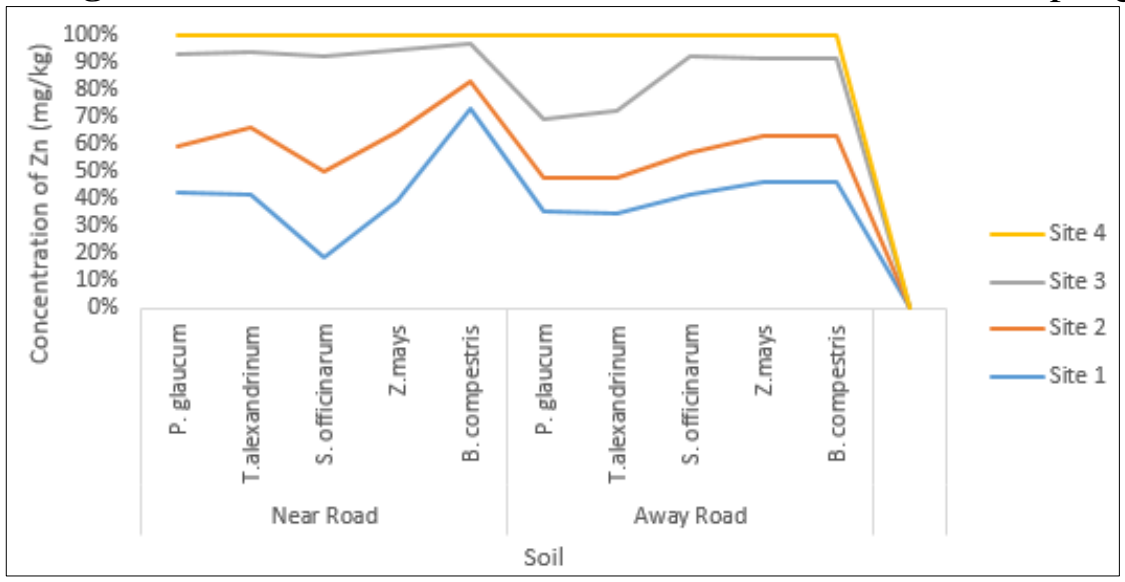

Figure 4. Zn fluctuations in Soil from four road sites of sampling 


\subsection{Bio concentration Factor}

The highest mean concentration of Bio concentration factor was $5.646365 \mathrm{mg} / \mathrm{kg}$ in S.officinarumat a distance from the road while lowest in Z.mays $0.214276 \mathrm{mg} / \mathrm{kg}$ present near the road edge (Table 11). The Highest bio concentration of $\mathrm{Zn}$ was present in Z.mays samples of near roadside while lowest in S.officinarum samples collected away from the road (Table 12). The order of Bio concentration factor of the present study was $\mathrm{Pb}>\mathrm{Zn}$. The BCF concentration of $\mathrm{Zn}$ was $(0.349)$ lower as compared to the present study [36]. The bio concentration depends upon the $p \mathrm{H}$ of the soil and they do not easily transfer in the fodder plants $[22,37]$ Soil $p \mathrm{H}$ effects the mobility of metals in soil. Higher the soil $p \mathrm{H}$ causes low mobility of metals in soil [38]. It was reported that if the bio concentration factor is less than 1 no accumulation of metals occurred in soil. The higher bio concentration of metal indicates the higher range of its accumulation in plants [39].

Table 9. Bio concentration factor of $\mathrm{Pb}$ in fodders having contamination

from automobile emissions

\begin{tabular}{|c|c|c|c|c|c|c|}
\hline Sites & Treatments & P.glaucum & T.alexandrinum & S.officinarum & Z.mays & B.compestris \\
\hline \multirow{2}{*}{ Site 1 } & AR & 1.1315 & 1.0272 & 1.0537 & 0.6517 & 0.9160 \\
\cline { 2 - 7 } & NR & 0.7659 & 1.040 & 1.2910 & 1.0177 & 1.2857 \\
\hline \multirow{2}{*}{ Site 2 } & AR & 1.0697 & 0.9276 & 0.8579 & 0.7499 & 0.8276 \\
\cline { 2 - 7 } & NR & 1.0223 & 0.2259 & 0.5522 & 0.5998 & 0.2767 \\
\hline \multirow{2}{*}{ Site 3 } & AR & 0.2717 & 0.299 & 0.2980 & 1.3746 & 0.880 \\
\cline { 2 - 7 } & NR & 0.7232 & 0.930 & 0.823 & 0.2142 & 1.1537 \\
\hline Site 4 & AR & 1.0630 & 1.0996 & 5.6463 & 5.3276 & 3.0283 \\
\cline { 2 - 7 } & NR & 3.1647 & 4.8887 & 3.0086 & 3.4217 & 0.6096 \\
\hline
\end{tabular}

Table 10. Bio concentration of $\mathrm{Zn}$ in fodders from four sites of sampling having heavy traffic load

\begin{tabular}{|c|c|c|c|c|c|c|}
\hline Sites & Treatments & P.glaucum & T.alexandrinum & S.officinarum & Z.mays & B.compestris \\
\hline \multirow{2}{*}{ Site 1 } & AR & 1.0558 & 1.0889 & 1.0548 & 0.3628 & 0.967 \\
\cline { 2 - 7 } & NR & 0.9499 & 0.8757 & 2.7011 & 0.898 & 0.1142 \\
\hline \multirow{2}{*}{ Site 2 } & AR & 1.2595 & 1.2485 & 0.4367 & 0.484 & 0.8974 \\
\cline { 2 - 7 } & NR & 1.086 & 0.3212 & 0.5816 & 0.6317 & 0.3287 \\
\hline \multirow{2}{*}{ Site 3 } & AR & 0.3291 & 0.2483 & 0.2294 & 1.1511 & 0.8903 \\
\cline { 2 - 7 } & NR & 0.8256 & 0.8501 & 0.7389 & 0.2737 & 0.7694 \\
\hline \multirow{2}{*}{ Site 4 } & AR & 0.772 & 0.7855 & 4.566 & 3.4699 & 3.9075 \\
\cline { 2 - 7 } & NR & 4.4998 & 4.8043 & 4.7406 & 5.1375 & 5.0255 \\
\hline
\end{tabular}

\subsection{Correlation}

The positive and non-significant correlation was found in Soil-P. glaucum and Soil-B. compestris and the negative non-significant correlation was present in Soil-T.alexandrinum, Soil-S.officinarum and Soil-Z.mays (Table 13). The Zn correlation coefficient showed the negative non-significant correlation in Soil-S.officinarum, Soil-Z.mays and Soil-B. compestris (Table 14). The positive non-significant correlation was present in Soil-P.glaucum and Soil-T.alexandrinum. The current study showed the nonsignificant correlation of $\mathrm{Pb}$ and $\mathrm{Zn}$. According to Onjefu et al., [53] $\mathrm{Fe}, \mathrm{Mn}, \mathrm{Ni}, \mathrm{Zn} \mathrm{Cr}$ showed the strong ( $r>0.5$ to 0.9 ) and extremely strong $(r>0.9)$ positive correlation while the $\mathrm{Pb}$ showed weak positive correlation ( $\mathrm{r}=0.3524$ ). According to Nazzal et al. [54] $\mathrm{Pb}, \mathrm{Mn}, \mathrm{Ni}, \mathrm{Fe}, \mathrm{Cd}$ have showed the significant positive correlation As compared with current study in which the heavy metal $\mathrm{Pb}$ showed negative non-significant correlation.

Table 11. Correlation between $\mathrm{Pb}$ concentrations of soil to fodders from four road sites

\begin{tabular}{|l|l|}
\hline Correlation Coefficient \\
\hline Soil-P.glaucum & 0.269 \\
\hline Soil-T.alexandrinum & -0.011 \\
\hline Soil-S.officinarum & -0.411 \\
\hline Soil-Z.mays & -0.476 \\
\hline Soil-B. compestris & 0.518 \\
\hline
\end{tabular}


Table 12. Correlation between $\mathrm{Zn}$ concentrations of soil to fodders from four road sites

\begin{tabular}{|l|l|}
\hline Correlation Coefficient \\
\hline Soil-P.glaucum & 0.523 \\
\hline Soil-T.alexandrinum & 0.298 \\
\hline Soil-S.officinarum & -0.103 \\
\hline Soil-Z.mays & -0.105 \\
\hline Soil-B. compestris & -0.170 \\
\hline
\end{tabular}

\subsection{Daily intake and health risk index}

The Highest value of Daily intake of $\mathrm{Pb}$ was found in nearby road sample of Z.mays of site 4 while the lowest value was recorded in T.alexandrinum of site 2 (Table 15). The Highest value of Health risk of $\mathrm{Pb}$ was also found in the Z.mays of site 4 collected near the road while the lowest value was recorded in the B.compestris of site 3 collected near the road (Table 16). The highest daily intake concentration of $\mathrm{Zn}$ was calculated in site 1 T.alexandrinum sample taken far away from the road. The lowest value was found in the away road sample of S.officinarum of site 2. The highest concentration of $\mathrm{Zn}$ in health risk index was found in the B.compestris of site 1 of away road sample while the lowest value was found in the away road sample of S.officinarum of site 2. The order of Daily intake of metals in animals was in the order $\mathrm{Pb}>\mathrm{Zn}$ in the current study. The daily intake of $\mathrm{Pb}$ was lower in the present study as compared to given by Guerra et al., [42]. The daily intake of metals in the present study lower than 1, indicates no risk of health for livestock via consumption as reported by Radwan and Salama [43]. Our present study showed the order of health risk index as $\mathrm{Pb}>\mathrm{As}>\mathrm{Cd}>\mathrm{Fe}>\mathrm{Zn}>\mathrm{Ni}>\mathrm{Mn}>\mathrm{Cr}$. The health risk index was obtained by using the oral reference dose of the metals. The present study showed the health risk index of $\mathrm{Pb}, \mathrm{Cr}, \mathrm{Cd}, \mathrm{Zn}$ were higher as compared to Ali et al., [44]. but the health risk of $\mathrm{Ni}$ was lower in the present study. According to Khan et al., the health risk of Mn was higher as compared to present study. The concentration of heavy metal greater than 1 showed high risk of health for livestock Sajjadet al., [45]. The metal accumulation even at very low level in liver and kidney cause abnormality of metabolism and health risk for both wildlife and livestock[46,47]. Forages growing in polluted environment such as along roadsides accumulates toxic metals in high concentration which poses danger to the life of animals and enters the food chain and cause detrimental effects [48]. Increase concentration of lead in the forage samples along roadsides cause restriction of root expansion and cell division and cell elongation [49]. The highest mean concentration of lead from vehicle exhaust enters the food chain and cause serious problems in kidneys, liver, central nervous system, reproductive system and anemia in humans [50].

Table 13. Daily intake of $\mathrm{Pb}$ and health risk from fodders of the four road sites

\begin{tabular}{|c|c|c|c|c|c|c|c|}
\hline Sites & $\begin{array}{c}\text { Treatme } \\
\text { nts }\end{array}$ & $\begin{array}{c}\text { DIM\& } \\
\text { HRI }\end{array}$ & P.glaucum & T.alexandrinum & S.officinarum & Z.mays & B.compestris \\
\hline \multirow[t]{4}{*}{ Site 1} & \multirow[t]{2}{*}{$\mathrm{AR}$} & DIM & 0.0136 & 0.0145 & 0.013 & 0.0083 & 0.013 \\
\hline & & HRI & 3.89 & 4.168 & 3.8001 & 2.3915 & 3.77 \\
\hline & \multirow[t]{2}{*}{ NR } & DIM & 0.0120 & 0.012 & 0.0146 & 0.0143 & 0.009 \\
\hline & & HRI & 3.431 & 3.5759 & 4.186 & 4.095 & 2.85 \\
\hline \multirow[t]{4}{*}{ Site 2} & \multirow[t]{2}{*}{$\mathrm{AR}$} & DIM & 0.00857 & 0.0101 & 0.0070 & 0.0063 & 0.0092 \\
\hline & & HRI & 2.4496 & 2.897 & 2.00384 & 1.824 & 2.635 \\
\hline & \multirow[t]{2}{*}{ NR } & DIM & 0.0094 & 0.004 & 0.008 & 0.0094 & 0.00427 \\
\hline & & HRI & 2.7103 & 1.228 & 2.5709 & 2.707 & 1.222 \\
\hline \multirow[t]{4}{*}{ Site 3} & \multirow[t]{2}{*}{$\mathrm{AR}$} & DIM & 0.0044 & 0.0058 & 0.00595 & 0.0227 & 0.017 \\
\hline & & HRI & 1.2643 & 1.684 & 1.7025 & 6.513 & 4.87 \\
\hline & \multirow[t]{2}{*}{ NR } & DIM & 0.0184 & 0.018 & 0.0183 & 0.0048 & 0.025 \\
\hline & & HRI & 5.2789 & 5.386 & 5.2452 & 1.374 & 7.19 \\
\hline
\end{tabular}




\begin{tabular}{|c|c|c|c|c|c|c|c|}
\hline Site 4 & AR & DIM & 0.022 & 0.025 & 0.0222 & 0.020 & 0.020 \\
\cline { 3 - 8 } & & HRI & 6.4907 & 7.229 & 6.37 & 5.89 & 5.962 \\
\cline { 2 - 8 } & \multirow{2}{*}{ NR } & DIM & 0.0230 & 0.019 & 0.0208 & 0.023 & 0.023 \\
\cline { 3 - 8 } & & HRI & 6.599 & 5.62 & 5.944 & 6.695 & 6.63 \\
\hline
\end{tabular}

Table 14. Daily intake and health risk of $\mathrm{Zn}$ from fodders polluted with traffic exhaust from four sites

\begin{tabular}{|c|c|c|c|c|c|c|c|}
\hline Sites & $\begin{array}{c}\text { Treatme } \\
\text { nts }\end{array}$ & $\begin{array}{c}\text { DIM\& } \\
\text { HRI }\end{array}$ & P.glaucum & T.alexandrinum & S.officinarum & Z.mays & B.compestris \\
\hline \multirow[t]{4}{*}{ Site 1} & \multirow[t]{2}{*}{$\mathrm{AR}$} & DIM & 0.0203 & 0.0208 & 0.0205 & 0.008 & 0.021 \\
\hline & & HRI & 0.067 & 0.069 & 0.0686 & 0.027 & 0.0712 \\
\hline & \multirow[t]{2}{*}{ NR } & DIM & 0.0206 & 0.0197 & 0.0208 & 0.019 & 0.0090 \\
\hline & & HRI & 0.068 & 0.065 & 0.069 & 0.066 & 0.03 \\
\hline \multirow[t]{4}{*}{ Site 2} & \multirow[t]{2}{*}{$\mathrm{AR}$} & DIM & 0.0081 & 0.00911 & 0.0029 & 0.004 & 0.0069 \\
\hline & & HRI & 0.027 & 0.030 & 0.0099 & 0.013 & 0.023 \\
\hline & \multirow[t]{2}{*}{ NR } & DIM & 0.0097 & 0.0044 & 0.0074 & 0.008 & 0.0036 \\
\hline & & HRI & 0.0326 & 0.014 & 0.0249 & 0.0292 & 0.012 \\
\hline \multirow[t]{4}{*}{ Site 3} & \multirow[t]{2}{*}{$\mathrm{AR}$} & DIM & 0.0038 & 0.0033 & 0.0037 & 0.0156 & 0.0120 \\
\hline & & HRI & 0.0129 & 0.0110 & 0.0126 & 0.052 & 0.040 \\
\hline & \multirow[t]{2}{*}{ NR } & DIM & 0.0142 & 0.0126 & 0.0128 & 0.0045 & 0.011 \\
\hline & & HRI & 0.0475 & 0.0421 & 0.0426 & 0.015 & 0.039 \\
\hline \multirow[t]{4}{*}{ Site 4} & \multirow[t]{2}{*}{ AR } & DIM & 0.0130 & 0.0121 & 0.0169 & 0.015 & 0.016 \\
\hline & & HRI & 0.043 & 0.040 & 0.0565 & 0.0507 & 0.055 \\
\hline & \multirow[t]{2}{*}{ NR } & DIM & 0.016 & 0.0174 & 0.0158 & 0.0170 & 0.0169 \\
\hline & & HRI & 0.0551 & 0.058 & 0.0528 & 0.056 & 0.056 \\
\hline
\end{tabular}

\subsection{Pollution Load index}

The highest pollution load index of $\mathrm{Pb}$ was examined in P.glaucum growing near road of site 3 and lowest was found in away road sample of Z.mays of site 4 (Table 17). The pollution load index of $\mathrm{Zn}$ in fodders soil was found highest in T.alexandrinum of site 1 collected near the road while the lowest concentration was found in the Z.mays of site 4 taken near the road side (Table 18). The pollution load index of $\mathrm{Zn}, \mathrm{Pb}, \mathrm{Mn}$ and $\mathrm{Fe}$ was higher as compared to the present study. The pollution load index of $\mathrm{Pb}$ and $\mathrm{Zn}$ in the current study is lower as obtained by Mmolawa [35]. The pollution load index will be equal to 1 than plants are contaminated by pollutants, if PLI $<1$ it shows excellence level and if PLI $>1$ it shows the site is deteriorated with anthropogenic activities [40]. As in the present study the highest concentration of pollution load index Of $\mathrm{Zn}$ showed that it directly relates with traffic density and distance from the road. As the distance of soil sample from the road decreases the level of its concentration becomes low [41].

Table 15. Pollution Load Index of $\mathrm{Pb}$ in soil samples from four road sites

\begin{tabular}{|c|c|c|c|c|c|c|}
\hline Sites & Treatments & P.glaucum & T.alexandrinum & S.officinarum & Z.mays & B.compestris \\
& & & & & & \\
\hline \multirow{2}{*}{ Site 1} & AR & 0.07336 & 0.0864 & 0.0768 & 0.0782 & 0.0878 \\
& NR & 0.0954 & 0.0732 & 0.0691 & 0.0857 & 0.0473 \\
\hline \multirow{2}{*}{ Site 2 } & AR & 0.0488 & 0.0665 & 0.0497 & 0.0518 & 0.0678 \\
\cline { 2 - 7 } & NR & 0.0565 & 0.1159 & 0.0992 & 0.0962 & 0.0941 \\
\hline \multirow{2}{*}{ Site 3 } & AR & 0.0991 & 0.1198 & 0.1217 & 0.101 & 0.1180 \\
\cline { 2 - 7 } & NR & 0.1555 & 0.1233 & 0.1358 & 0.1366 & 0.1328 \\
\hline Site 4 & AR & 0.13011 & 0.1401 & 0.024 & 0.0235 & 0.0419 \\
\cline { 2 - 7 } & NR & 0.0444 & 0.0245 & 0.0421 & 0.0417 & 0.231 \\
\hline
\end{tabular}


Table 16. Pollution Load Index of $\mathrm{Zn}$ in soil from four sampling sites facing high traffic density

\begin{tabular}{|c|c|c|c|c|c|c|}
\hline Sites & Treatments & P.glaucum & T.alexandrinum & S.officinarum & Z.mays & B.compestris \\
\hline \multirow{2}{*}{ Site 1} & AR & 0.200 & 0.1978 & 0.2021 & 0.2315 & 0.2285 \\
\cline { 2 - 7 } & NR & 0.224 & 0.2339 & 0.0799 & 0.228 & 0.8175 \\
\hline \multirow{2}{*}{ Site 2 } & AR & 0.066 & 0.0755 & 0.0711 & 0.0872 & 0.0802 \\
\cline { 2 - 7 } & NR & 0.0932 & 0.1431 & 0.1333 & 0.144 & 0.1146 \\
\hline \multirow{2}{*}{ Site 3 } & AR & 0.1223 & 0.1379 & 0.1710 & 0.1411 & 0.1401 \\
\cline { 2 - 7 } & NR & 0.1786 & 0.1538 & 0.17936 & 0.1713 & 0.1580 \\
\hline \multirow{2}{*}{ Site 4 } & AR & 0.1750 & 0.1601 & 0.0384 & 0.045 & 0.0438 \\
\cline { 2 - 7 } & NR & 0.038 & 0.0376 & 0.034 & 0.034 & 0.0348 \\
\hline
\end{tabular}

\subsection{Enrichment factor}

The highest value of $\mathrm{Pb}$ concentration was observed in S.officinarum of site 4 collected away from the road, while the lowest value was observed in Z.mays of site 3 collected from the roadside. The highest enrichment factor of $\mathrm{Zn}$ metal was determined in near road sample of Z.mays while the lowest concentration was present in away road sample of B. compestris of site 2. Sulaiman and Hamzah, reported the enrichment factor of $\mathrm{Pb}$ and $\mathrm{Cd}$ which was lower as compared to the current study [51]. The enrichment factor of $\mathrm{Pb}$ in the present study was higher. Their study showed the range of enrichment factor from moderate contamination to considerable contamination. Enrichment factor is the concentration of heavy metal present in the soil. The present study showed the order of enrichment factor as $\mathrm{Zn}>\mathrm{Pb}$. The study reported by Amieret al., the concentration of $\mathrm{Pb}$ showed extremely high enrichment as compared to present study which showed the lower enrichment concentration [52].

Table 17. Enrichment factor of $\mathrm{Pb}$ in soil polluted with automobile emissions from four sites of sampling

\begin{tabular}{|c|c|c|c|c|c|c|}
\hline Sites & Treatments & P.glaucum & T.alexandrinum & S.officinarum & Z.mays & B.compestris \\
\hline \multirow{3}{*}{ Site 1 } & AR & 48.09072 & 43.65869 & 44.78521 & 27.698 & 38.93402 \\
\cline { 2 - 7 } & NR & 32.55534 & 44.20233 & 54.86942 & 43.25444 & 54.64728 \\
\hline \multirow{2}{*}{ Site 2 } & AR & 45.46648 & 39.42603 & 36.46178 & 31.87387 & 35.1777 \\
\cline { 2 - 7 } & NR & 43.45199 & 9.604651 & 23.47072 & 25.49359 & 11.76228 \\
\hline \multirow{2}{*}{ Site 3 } & AR & 11.54785 & 12.73879 & 12.66772 & 58.4228 & 37.43114 \\
\cline { 2 - 7 } & NR & 30.73996 & 39.5567 & 34.98788 & 9.106884 & 49.03556 \\
\hline Site 4 & AR & 45.18216 & 46.73487 & 239.9747 & 226.4312 & 128.7067 \\
\cline { 2 - 7 } & NR & 134.5056 & 207.7746 & 127.8679 & 145.4257 & 25.91066 \\
\hline
\end{tabular}

Table 18. Enrichment factor of $\mathrm{Zn}$ in soil polluted with vehicular emissions from four sites of sampling

\begin{tabular}{|c|c|c|c|c|c|c|}
\hline Sites & Treatments & P.glaucum & T.alexandrinum & S.officinarum & Z.mays & B.compestris \\
\hline \multirow{3}{*}{ Site 1 } & AR & 87.99069 & 90.74857 & 87.90598 & 30.23355 & 80.64916 \\
\cline { 2 - 7 } & NR & 79.16154 & 72.98211 & 225.0967 & 74.8925 & 9.518858 \\
\hline \multirow{2}{*}{ Site 2 } & AR & 104.9585 & 104.0471 & 36.39709 & 40.36079 & 74.78979 \\
\cline { 2 - 7 } & NR & 90.55664 & 26.77149 & 48.4713 & 52.64236 & 27.39258 \\
\hline \multirow{2}{*}{ Site 3 } & AR & 27.42892 & 20.69563 & 19.12294 & 95.93042 & 74.19448 \\
\cline { 2 - 7 } & NR & 68.80505 & 70.84341 & 61.57727 & 22.81615 & 64.12195 \\
\hline Site 4 & AR & 64.39506 & 65.4643 & 380.56 & 289.1617 & 325.6327 \\
\cline { 2 - 7 } & NR & 374.9912 & 400.3614 & 395.0573 & 428.1305 & 418.792 \\
\hline
\end{tabular}

\section{Conclusions}

Atmospheric pollution is the major cause of these metals in soil and plants. Vehicle exhaust is the source of atmospheric pollution. The current study reported that the natural weathering of building materials, emissions from industries, bricks kilns, and heating systems burning of fuel also cause the heavy metal pollution but the vehicles are also the source of its accumulation in plant and animal bodies.

The pollution of heavy metals from automobiles is of serious environmental issue. Due to increase in population the traffic burden is also increasing day by day. The present study was done on the fodder samples along roadside environment. Fodder plants and soil are facing high concentration of heavy metal 
pollution originating from busy roads in the vicinity of suburbs and contribution of high traffic density to high level of exhaust emissions.

Samples analyzed in the current study have low and high values of heavy metals from the permissible limits. The heavy metal concentration is strongly and inversely correlated with distance from the road. Lead and Zinc are major metals present in roadside environment and they are released from burning of fuels, tyres and through leakage of oils. Heavy metal from vehicles exhaust are very toxic for living organisms. Even some trace elements are essential for plants but they become toxic if their occurrence exceed the limit.

Acknowledgment. The authors extend their appreciation to the Researchers Supporting Project Number (RSP-2020/94) King Saud University, Riyadh, Saudi Arabia

\section{References}

1. TRIPATHI, A.K. M. GAUTAM, M., Biochemical parameters of plants as indicators of air pollution. Journal. Environmental. Biology, 28, 2007, 127-132.

2. TRIVIDY, R.K., Advance in environmental science and technologY., Ashish publishing house, New Dehli. 1, 1995, 227.

3.WOO, S.Y., JE, S.M., Photosynthetic rates and antioxidant enzyme activity of Platanusoccidentalis growing under two levels of air pollution along the streets of Seoul. Journal of Plant Biology.,49, 2006, 315-319.

4. RAI, A., KULSHRESHTHA, K., SRIVASTAVA, PK., MOHANTY CS., Leaf surface structure alterations due to particulate pollution in some common plants. The Environmentalis.,30, 2010,18-23. 5. JOSHI, N., CHUHAN, A., JOSHI, P.C., Impact of industrial air pollutants on some biochemical parameters and yield in wheat and mustard plants. Environmentalist.,29, 2009, 398-404.

6. AGBAIRE, P. O., Air Pollution Tolerance Indices (APTI) of some plants around Otorogun gas plant in Delta State, Nigeria. Journal of Applied Science and Environmental Management., 13, 2009, 11-14.

7. LIU, Y.J., DING, H., Variation in air pollution tolerance index of plants near a steel factory: Implications for landscape-plant species selection for industrial areas. WSEAS Transactions on Environment and Development., 4, 2008, 24-32.

8. GILLOOLY, S. E., SHMOOL, J.L.C., MICHANOWICZ, D.R., Framework for using deciduous tree leaves as biomonitors for intraurban particulate air pollution in exposure assessment. Environmental Monitoring and Assessment, 188, 2016, 479.

9. NOMAN, A., M. AQEEL., M. JAVED, ZAFAR, S., ALI, Q., ISLAM, W., IRSHAD, M.K., BURIRO, M., KANWAL, H., KHALID, N., KHAN, N., Histological changes in Hibiscus rosasinensis endorse acclimation and phytoremediation of industrially polluted sites. Journal of Animal Plant Science.,27 (5), 2017, 1637-1648.

10. BELL, J., HONOUR, S.L., POWER S.A., Effects of vehicle exhaust emissions on urban wild plant species. Environmental Pollution.,159 (8-9), 2011,1984-1990.

11.ARSHAD, M., ALI, S., NOMAN, A., ALI, Q., RIZWAN, M., FARID, M., IRSHAD, M.K., Phosphorus amendment decreased cadmium $(\mathrm{Cd})$ uptake and ameliorates chlorophyll contents, gas exchange attributes, antioxidants, and mineral nutrientsin wheat (Triticumaestivum L.) under Cd stress. Archives Agronology and Soil Science, 62(4), 2016, 533-546.

12. KIM, K., KABIR, H.E., KABIR, S., A review on the human health impact of airborne particulate matter. Environ International, 74, 2015, 136-143.

13. LAUMBACH, R., MENG, Q., KIPEN, H., What can individuals do to reduce personal health risks from air pollution? Journal of Thoracic Disease,7(1), 2015, 96-00. 
14. IERODIAKONOU, ZANOBETTI, D.E., COULL, B.A., MELL, S., POSTMA, S.D., BOEZEN, H.M., VONK, J.N., WILLIAMS, P.V., SHAPIRO, G.G., MCKONE, E.F., HALSTRAND, T.S., KOEING, J.Q., SCHILDCROUT, S.J., LUMLEY, T., FUHLBRIGGE, A.N., KOUTRAKIS, P., SCHWARTZ, J., WEISS, S.T., GOLD, D.R., Ambient air pollution, lung function, and airway responsiveness in asthmatic children. Journal of Allergy and Clinical Immunology, 137(2), 2016, 390 399.

15. LELIEVELD, J., EVANS, J.S., FNAIS, M., GIANNDAKI, D., POZZER, A., The contribution of outdoor air pollution sources to premature mortality on a global scale. Nature.,525, (7569), 367-371.

16. BAI, Y., BRUGHA, R.E., JACOBS, L., GRIGGS, J., NAWROT, T.S., NEMRY, B., Carbon loading in airway macrophages biomarker for individual exposure to particulate matter air pollution - A critical review. Environment International, 74, 2015, 32-41.

17. TIWARI. S., M. AGRAWAL., MARSHALL, F.M., Evaluation of ambient air pollution impact on carrot plants at a sub urban site using open top chambers. Environmental Monioring Assessment., 119, 2006, 15-30.

18.DINEVA, S.B., Comparative studies of the leaf morphology and structure of white ash Fraxinusamericana L. and London plane tree Platanusacerifolia Willd growing in polluted area. Dendrobiology.,52, 2004, 3-8.

19. JAHAN, S., IQBAL, M.Z., Morphological and anatomical studies on leaves of different plants affected by motor vehicle exhusted. Journal of Islamic Academy and Science, 5, 1992, 21-23.

20. DEY, S., STAFFORD, R., DEBROY, M.K., CR. BHATTACHARJEE, KHATING, DT., BHATTCHARJEE, PC., DKHAR, PS., Metal toxicity and trace elementdeficiency in some wild animals fromNorth-east India, as revealed by cellular, bio-inorganicandbehavioural studies. Current Science, 77, 1999, 276-280.

21. STEL, R.G., TORRIE, D.J.H., Principles and procedures of statistics. A Biometrical Approach (2nd Ed.). New York: McGraw Hill Book Co, p.1.1980.

22. CUI, Y.L., ZHU, R.H., ZHI, R.H., CHEN, D.Y., HUANG, Y.Z., QIU, Y., Transfer of metals from soils to vegetables in an area near a smelter in Nanning, China. Environment International, 30, 2004,785791.

23. CHARRY, N., KAMALA, C.T., RAJ, D.S., Assessing risk of heavy metals from consuming food grown on sewage irrigated soils and food chain transfer. Ecotoxicol Environmental Safety, 69(3), 2008, 513-524.

24. BRIGGS, H., BRIGGS, H.M., Modern breeds of livestock. Fourth edition Mc Million publishing Co. pp: 234-239.

25.*** USEPA (US Environmental Protection Agency), 2002. Region 9, Preliminary Remediation Goals.

26. HWAITI.M., OMAR. A.K., LAILA. A.K., FERAS, F., Radiological hazard assessment for building materials incorporating phosphogypsum made using Eshidiya mine rock in Jordan. Environmental Earth Science, 71, 2013, 2257-226.

27. LIU. W., H. ZHAO. J.Z., OUYUANG, SODERLUND, Z.Y., LIU ,L., Impacts of sewage irrigation on heavy metal distribution and contamination in Beijing, China. Environmental International 31, 2005, 805-812.

28.MOREKI, D.J.C., WOODS, T.O., NTHOIWA, P.G., Estimation of the concentration of heavy metals in forages harvested around dibete area, Botswana, Journal International Journal of Innovative Research in Science, Engineering and Technology, 2 (8), 2013, 4060-4071.

29. OGUNDELE., D.T.I., ADIO, AA2., OLUDELE, O. E., Heavy Metal Concentrations in Plants and Soil along Heavy Traffic Roads in North Central Nigeria. Enviroenmnetal and Analytical Toxicology, 5:6.

30. KHALID, N., M. HUSSAIN, H.S. YOUNG, M. ASHRAF, M. HAMEED, R. AHMAD., Lead concentrations in soils and some wild plant species along two busy roads in Pakistan. Bulletin Environmental ContaminationToxicology, 100 (2), 2018, 250-258. 
31. AHMAD, K., SHAHEEN, M., KHAN, Z.I., BASHIR, H., Heavy metals contamination of soil and fodder possible risk to livestock. Journal of science and technology, 32 (2), 2013, 140-148.

32. ABECHI, E.S., OKUNOL, A., ZUBAIRU, O.J., S.M.J, USMAN, A. A., APENNE, E., Evaluation of heavy metals in roadside soils of major streets in Jos metropolis, Nigeria. Journal of Environmental Chemistry and Ecotoxicology, 2(6), 2010, 98- 102.

33. BAI, J., CUI, B., WANG, Q., GAO, H, DING, Q., Assessment of heavy metal contamination of roadside soils in Southwest China. Stoch. Environmental. Research Risk Assessment

34. OPULWA, O.D., AREMU, M.O., OGBO, L.O., ABIOLA, K.A., ODIBA, I.E., ABUBAKAR, M.M., NWEZE, N.O., Heavy metal concentrations in soils, plants leaves and crops grown around dump sites in Lafia Metropolis, Nasarawa State, Nigeria. Advances in Applied Science Research, 3 (2), 2012, 780 784.

35. MMOLAWA, K., LIKUKU, B.A.S., GABOUTLOELOE, G.K., Assessment of heavy metal pollution in soils along major roadside areas in Botswana. African Journal of Environmental Science, Technol, 5(3), 2011, 186-196.

36. JIA, L., WANG, W., LI, Y., YAMG, L., Heavy Metals in Soil and Crops of an Intensively Farmed Area: A Case Study in Yucheng City, Shandong Province, China, Journal of Environmental Research and Public Health, 7, 2010,395-412.

37. ZHANG, C., LOU, S.H., SONG, Y. S., ZHANG, J., XIA, H., ZHAO, J., Predicting As, Cd and Pb uptake by rice and vegetables using fields data from China. Journal of Environmental Science, 23, 2007, 70-78.

38. CELECHOVSKA, O., MALOTA, L., ZIMA, S., Entry ofheavy metals into food chains: a 20yearscomparison study in Northern Moravia (CzechRepublic). Acta Vet Brno, 77, 2008, 645 - 652.

39. LIU, W., ZHAO, J.Z., OUYANG, Z.Y., SODERLUN, L., LIU, G.H., Impacts of sewage irrigation on heavy metals distribution and contamination. Environmental International, 31, 2006, 805-812.

40. THOMILSON, D., WILSON, C., HARRIS, D.J., JEFFREY, D.W., Problem in heavy metals in estuaries and the formation of pollution index. Helgol. Wiss. Meeresunlter. 33(1-4), 1980, 566575.

41. FATOKI, O.S., Lead, Cadmium and Zinc accumulation on soil and vegetable along Some selected major roads (pollution load index) 2003.

42. GUERRA, F., TREVIZAM, A.R., MURAOKA, T., MARCANTE, N.C., BRAZACA, S.G.C., Heavy metals in vegetables and potential risk for human health. Science Agriculture., 69 (1), 2011,5460.

43. RADWAN, M.N., SALMA, A.K., Market basket survey for some heavy metals in Egyptian fruits and vegetables. Food Chemistry Toxicology., 44, 2006, 1273-1278.

44. Ali, F., ULLAH, H., KHAN, I., Heavy Metals Accumulation in Vegetables Irrigated with Industrial Influents and Possible Impact of such Vegetables on Human Health. SarhadJournal of Agriculture, 33(3), 2017, 489-500

45. SAJJAD, K., FAROOQ, R., SHAHBAZ, S., KHAN, M.A., SIDDIQUE, M., Health risk assessment of heavy metals for population via consumption of vegetables. World Applied Science Journal., 6, 2009, 1602-1606.

[46]MIRANDA, M., LOPEZ-ALONSO, M., CASTILLO, C., HERMANDEZ,J., and BENDITO, J.L., Effects of moderate pollution on toxic and trace metal levels in calves from a polluted area of northern Spain. Environmental International.,31 (4), 2005, 543-548.

47.RODRIGUEZ-ESTIVAL.J., BARASONA, J.A., MATEO., Blood Pb and $\delta$ - ALAD inhibition in cattle and sheep from Pb-polluted mining area. Environmental Pollution, 160, 2012, 118-124.

48. ALLOWAY, B.J., Heavy metal in soil .2 ${ }^{\text {nd }}$ ed Glasglow Blackie and Son Publishers, England, 1990, 339

49. EUN, SO., YOUN, H.S., LEE, Lead disturbs microtubule organization in root meristem of Zea mays. Physiology of Plant, 110, 2000, 357-365. 
50.LUILO, G.B., OTHMAN, O.C., Lead pollution in urban roadside environments of dares International Office of Cocoa, Chocolate and Sugar Confectionery. Paper on the position of IOCCC on heavy metal contamination in the confectionery industry (IOCCC). 1996.

51.SULAIMAN, F.R., HAMZAH, H.A., Heavy metals accumulation in suburban roadside plants of a tropical area (Jengka, Malaysia), Ecological Process, 7, 2018, 28.

52.EL-AMIER, Y.A., SULIMAN, ALGHANEM, M., EL-ALFY, M.A., Ecological Risk Assessment of Heavy Metal Pollution in Top soil of Mediterranean Coast: A Case Study of Mareotis Coast, Egypt. Journal by Innovative Scientific Information \& Services Network, 15(3), 2018, 2626-2639.

53.ONJEFU, S.A., ABAH, J., NAMBUNDUNGA, B., Some Heavy Metals' Concentrations in Roadside Dusts at Monte Christo, Windhoek Namibia. JournalInternational Journal of Environmental Science and Development, 8(9), 2017, 647-652.

54. NAZZAL, Y., HABES, G.T., ROSEN, M.A., Application of Multivariate Geostatistics in the Investigation of Heavy Metal Contamination of Roadside Dusts from Selected Highways of the Greater Toronto Area, Canada. Journal of Environmental Earth Sciences, 2013, 259-273

Manuscript received: 1.07 .2020 